\title{
Does a Husband's Education Matter in Antenatal Care Visits Involvement?: Study on the Poor in Indonesia
}

\section{Agung Dwi Laksono}

Kementerian Kesehatan Republik Indonesia Badan Penelitian dan Pengembangan Kesehatan

Ratna Dwi Wulandari ( $\sim$ ratna-d-w@fkm.unair.ac.id)

Faculty of Public Health, Universitas Airlangga, Surabaya, Indonesia. Universitas Airlangga Campus C Mulyorejo, Surabaya, Indonesia 60115 https://orcid.org/0000-0003-4365-5747

\section{Ratu Matahari}

Ahmad Dahlan University School of Public Health: Universitas Ahmad Dahlan Fakultas Kesehatan Masyarakat

\section{Research article}

Keywords: education context, maternal health, women health, antenatal care, pregnancy care, husband's involvement

Posted Date: September 21st, 2020

DOl: https://doi.org/10.21203/rs.3.rs-76095/v1

License: (c) (i) This work is licensed under a Creative Commons Attribution 4.0 International License. Read Full License 


\section{Abstract}

Background: The husband's involvement in ANC is a form of the husband's responsibility for his wife's health. This study aims to analyze the effect of the husband's education level on the husband's involvement in ANC visits among the poor in Indonesia.

Methods: The study employed the 2017 Indonesian Demographic and Health Survey data. The unit of analysis was poor coupled with wives aged 15-49 years old and had been pregnant for the past five years. Samples of 6,414 couple were obtained. Besides the husband's education, other independent variables analyzed in this study were of the place of residence, age, occupation, and wife's parity. A binary logistic regression test was occupied in the final stage.

Results: The results showed that husbands who had primary education were 1.470 times more likely than no education husbands for husband's involvement in ANC visit. Husbands who have secondary education were likely 2.129 times compared to no education husband for husband's involvement. Meanwhile, a husband who has a higher education was probably 3.618 times compared to no education husband for husband's involvement. In addition to the education level, 3 other variables proved to be significantly influential on the husband's involvement in ANC visits among the people in Indonesia, namely place of residence, occupation, and wife's parity.

Conclusion: The husband's education level was a determinant of the husband's involvement in ANC visits among the poor in Indonesia. The better the education level, the more likely it is that husband's involvement in the ANC visit.

\section{Background}

Maternal and neonatal mortality is an indicator of health in an area marked by access and quality of antenatal care services so that it is included in the focus of Sustainable Development Goals (SDGs) ${ }^{1}$. Based on data from the World Health Organization (WHO) in 2017, it was explained that the maternal mortality rate in South-Eastern Asia reached 137/100,000 live births. Indonesia's position is the secondhighest in ASEAN after Laos in 2017 with an estimated number of maternal mortality cases of 305 cases per 100,000 live births ${ }^{2}$. This number is still far from the target set in the Millennium Development Goals (MDGs), which is 102 deaths per 100,000 live births and is then expected to achieve the SDGs target of 70 deaths per 100,000 live births ${ }^{3}$. Meanwhile, infant mortality in 2018 was 13 per 1000 live births ${ }^{4}$.

To reduce maternal and infant mortality rates, several programs have been implemented including the Safe Motherhood Program or "Mother's Love Movement" in 1990, then in the following decade the Making Pregnancy Safer Strategy program was implemented, and then the Expanding Maternal and Neonatal Survival program was implemented in 2012 which aims to improve the quality of obstetric and neonatal emergency services ${ }^{5}$. However, these efforts have not shown success ${ }^{6}$. Antenatal care (ANC) services have not been accessed as a whole, namely at least four times during pregnancy ${ }^{7,8}$. Research in 
Pakistan also shows that pregnant women have very little access to ANC services ${ }^{9}$. ANC services in Southeast Asia also vary, data shows that ANC coverage in Indonesia is higher than the Philippines and Timor Leste, namely $92 \%$. This also applies to the first ANC visit, namely Indonesia (86\%), Cambodia (83\%), and Myanmar (47\%) ${ }^{10}$.

The condition that attracts attention to the high maternal and infant mortality rates in Indonesia is the strong patriarchal culture. Patriarchal culture places women as subordinate subjects in social status, so there is a very weak bargaining position in making decisions about domestic needs when compared to husbands/spouses ${ }^{11-13}$. The influence of a strongly patriarchal culture makes the husband an important figure to support his wife to access maternal and child health services in developing countries in addition to meeting the economic needs of the wife ${ }^{14,15}$.

The dominant role of the husband as a decision-maker is very important to save mothers in a critical condition during pregnancy and childbirth. However, the fact is that the majority of husbands have minimal knowledge regarding maternal health during pregnancy and childbirth and seem to underestimate critical antenatal conditions, especially when the family's economic conditions are weak 16. Several literature studies in Indonesia explain that the husband has full autonomy in the decision to choose antenatal care $12,17,18$, If this condition is not balanced with a good level of education and knowledge, it will affect the quality of decision making ${ }^{1,19}$.

Seeing the very important role of husbands in preventing maternal and infant mortality, the Indonesian government in 2000 launched the "SUAMI SIAGA" program (Alert Husband). SIAGA is an abbreviation which means 'Slap' or awake/alert, meaning that the husband delivers and accompanies the mother to antenatal care during pregnancy or childbirth. obstetric and gynecological emergencies, and 'jaGA' which means looking after the wife during pregnancy and with the wife after childbirth ${ }^{20,21}$. To support this program, husbands are expected to have knowledge and understanding regarding antenatal care, emergency obstetric gynecology services, availability of transportation access to reach referral health services, and costs for accessing services ${ }^{21}$. Another study explained that the husband's knowledge regarding the process of preparing for childbirth was related to frequent access to information from the internet ${ }^{14}$. Not only that, but the husband's high education also has implications for promotion to access ANC services ${ }^{15}$.

Education and economic status are like interconnecting links. A study in India explains that poverty is a challenge in accessing maternal and child health services ${ }^{22}$. The level of someone's wealth is a factor that influences the pattern of access to health services, including institutional delivery ${ }^{23,24}$. The higher the level of wealth, the better education and knowledge that will influence behavior patterns in accessing health services ${ }^{25,26}$. Based on the dynamics of these problems, this study aims to analyze the effect of the husband's education level on the husband's involvement in ANC visits among the poor in Indonesia.

\section{Methods}




\section{Data Source}

The study was conducted using the 2017 Indonesian Demographic Data Survey (IDHS) data. The unit of analysis in this study was poor childbearing age couples. Couple with a wife aged 15-49 years old and had a pregnancy in the last five years before the interview. Samples were taken using stratification and multistage random sampling methods. A sample of 6,414 couples was collected.

\section{Data Analysis}

The husband's involvement was the respondent's acknowledgment of the husband's role in accompanying his wife during ANC visits. The poor were quintiles 1 and 2 of the family's wealth index. The wealth index was calculated based on wealth (number and type of goods owned). The wealth that counts was television to bicycle or car, and housing characteristics, such as sources of drinking water, toilet facilities, and the main building materials for the floor of the house. This score was calculated using principal component analysis. The national wealth quintile was compiled based on the household score for each person in the household and then divided by distribution into the same five categories, each accounting for $20 \%$ of the population 27 .

The education level was determined based on the last educational certificate the husband has. Education level was divided into 4 criteria, namely no education, primary, secondary, and higher. Other variables analyzed as independent variables were the type of place of residence, age group, occupation of husband, and parity of wife. The type of place of residence was divided into two categories, namely urban and rural. The division of the two categories of the type of place of residence follows the criteria determined by the Central Statistics Agency. Age was the respondent's acknowledgment of the husband's last birthday that has passed. The age group was divided into 5 categories, namely $<21,21-30,31-$ $40,41-50$, and $>50$. The husband's occupation type was the respondent's recognition of the type of field of work of the husband. Occupation type consists of 8 categories, namely did not work, professional/technical/managers/administration, clerical, sales, services, agricultural - self-employed, industrial worker, and other. The parity of wife was the respondent's acknowledgment of the number of live babies born to his wife. Parity is divided into 3 criteria, namely primiparous $(<2)$, multiparous $(2-4)$, and grand multiparous ( $>4)$.

At the initial stage, a colinearity test was carried out to ensure that there was no collinearity between the dependent and independent variables. Then the bivariate test was carried out using the chi-square test to see the relationship between the education level of husband and other variables. In the final stage, a binary logistic regression test was performed to determine the determinant and calculate the odds ratio. The entire analysis process uses the help of SPSS 22.

\section{Results}

Information about the results of the collinearity test can be seen in Table 1. The results of the analysis show that the tolerance value for all variables, between the dependent and independent variables, is > 
0.10 . Otherwise, the VIF value is $<10.00$. Based on the results of the analysis, it can be concluded that there are no multicollinearity symptoms in the regression model.

Table 1 Results for collinearity test of husband's involvement in ANC visits among the poor in Indonesia $(n=6,414)$

\begin{tabular}{|lll|}
\hline Variables & \multicolumn{2}{l|}{ Collinearity Statistics } \\
\cline { 2 - 3 } & Tolerance & VIF \\
\hline Education level & 0.895 & 1.117 \\
\hline Type of Place of Residence & 0.994 & 1.006 \\
\hline Age group & 0.711 & 1.407 \\
\hline Occupation & 0.924 & 1.082 \\
\hline Parity of wife & 0.711 & 1.405 \\
\hline
\end{tabular}

*Dependent Variable: Husband's involvement in ANC visit

Table 2 displays the results of the bivariate test between the education level of husband and other related variables. Table 2 informs that all education levels are dominated by husbands involved in ANC visits, except for no education husbands which are dominated by those who were not involved. Based on the type of place of residence, all education levels are dominated by husbands who live in rural areas. Meanwhile, based on the age group, all education levels were dominated by husbands in the 31-40 age group.

Based on the occupation of husband, all education levels are dominated by husbands who have an occupation in the agriculture - self-employed, except for husbands in the higher education category, which are dominated by professional/technical, managers and administration. Meanwhile, based on the parity of wife, all education levels are dominated by husbands with multiparous wives.

Table 2 The Results of Bivariate Analysis $(n=6,414)$ 
$\begin{array}{llll}\text { No } & \text { Primary Higher } \\ \text { Education } & \text { Secondary H }\end{array}$
n $\%$
n $\quad \%$
n $\quad \%$
n $\quad \%$

Husband's involved in ANC visit

$\begin{array}{lllllllll}\text { - No } & 89 & 57.1 \% & 1132 & 43.1 \% & 1050 & 32.2 \% & 82 & 22.3 \% \\ \text { - Yes } & 67 & 42.9 \% & 1495 & 56.9 \% & 2213 & 67.8 \% & 286 & 77.7 \%\end{array}$

\section{Type of place of} residence

$\begin{array}{lllllllll}\text { - Urban } & 25 & 16.0 \% & 605 & 23.0 \% & 1003 & 30.7 \% & 78 & 21.2 \% \\ \text { - Rural } & 131 & 84.0 \% & 2022 & 77.0 \% & 2260 & 69.3 \% & 290 & 78.8 \%\end{array}$

\section{Age groups}

$-<21$
$-\quad 21-30$
$-\quad 31-40$
$-41-50$
$->51$

1

$0.6 \% \quad 18$

$0.7 \% \quad 41$

$1.3 \%$

0.000

\section{Occupation}

$\begin{array}{llllllll}33 & 21.2 \% & 649 & 24.7 \% & 1148 & 35.2 \% & 160 & 43.5 \%\end{array}$

$\begin{array}{llllllll}63 & 40.4 \% & 1245 & 47.4 \% & 1484 & 45.5 \% & 160 & 43.5 \%\end{array}$

$39 \quad 25.0 \% \quad 618$

$23.5 \% \quad 514$

$15.8 \% \quad 42 \quad 11.4 \%$

$20 \quad 12.8 \% \quad 97$

$3.7 \% \quad 76$

$2.3 \% \quad 5$

$1.4 \%$

\begin{tabular}{|c|c|c|c|c|c|c|c|c|}
\hline - Did not work (ref.) & 3 & $1.9 \%$ & 10 & $0.4 \%$ & 27 & $0.8 \%$ & 16 & $4.3 \%$ \\
\hline $\begin{array}{l}\text { - } \\
\text { Professional/technical, } \\
\text { managers and } \\
\text { Administration }\end{array}$ & 2 & $1.3 \%$ & 41 & $1.6 \%$ & 155 & $4.8 \%$ & 137 & $37.2 \%$ \\
\hline
\end{tabular}

- Clerical

$1 \quad 0.6 \% \quad 8$

$0.3 \%$

117

$3.6 \%$

62

$16.8 \%$

- Sales

$9 \quad 5.8 \% \quad 195$

$7.4 \%$

305

$9.3 \%$

17

$4.6 \%$

- Services

$15 \quad 9.6 \% \quad 344$

$13.1 \% \quad 603$

$18.5 \% \quad 43$

- Agricultural - selfemployed

\begin{tabular}{|c|c|c|c|c|c|c|c|c|}
\hline - Industrial worker & 31 & $19.9 \%$ & 667 & $25.4 \%$ & 880 & $27.0 \%$ & 33 & $9.0 \%$ \\
\hline - Others & 1 & $0.6 \%$ & 13 & $0.5 \%$ & 27 & $0.8 \%$ & 5 & $1.4 \%$ \\
\hline
\end{tabular}

$\begin{array}{llllllll}94 & 60.3 \% & 1349 & 51.4 \% & 1149 & 35.2 \% & 55 & 14.9 \%\end{array}$




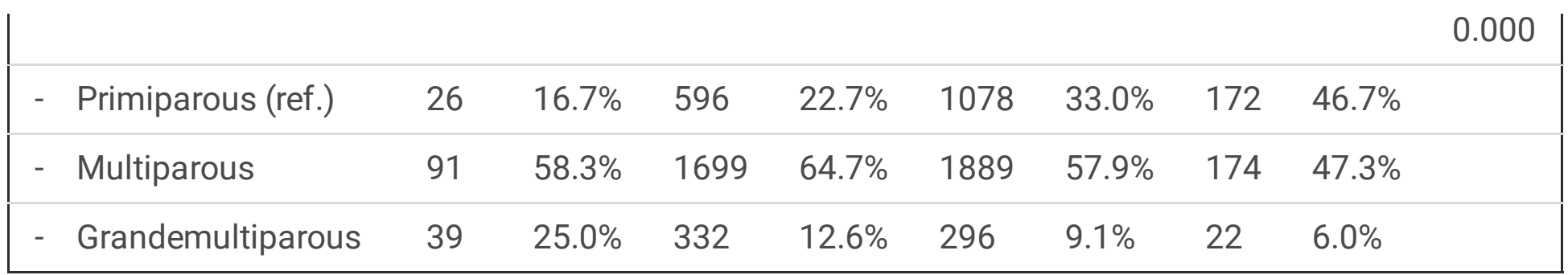

Note: $* \mathrm{p}<0.05 ; * * \mathrm{p}<0.01 ; * * * \mathrm{p}<0.001$.

Table 3 Binary logistic regression of husband's involvement in ANC visit among the poor in Indonesia $(n=6,414)$ 


\begin{tabular}{|c|c|c|c|c|}
\hline \multirow[t]{2}{*}{ Predictors } & \multicolumn{4}{|c|}{ Husband's Involvement in ANC visit } \\
\hline & Sig. & OR & $\begin{array}{l}\text { Lower } \\
\text { Bound }\end{array}$ & $\begin{array}{l}\text { Upper } \\
\text { Bound }\end{array}$ \\
\hline Education level: No education & - & - & - & - \\
\hline Education level: Primary & $\begin{array}{l}\star \star \\
0.025\end{array}$ & 1.470 & 1.050 & 2.058 \\
\hline Education level: Secondary & 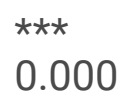 & 2.129 & 1.520 & 2.982 \\
\hline Education level: Higher & 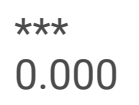 & 3.618 & 2.352 & 5.566 \\
\hline Type of place of residence: Urban & - & - & - & - \\
\hline Type of place of residence: Rural & 0.000 & 0.796 & 0.701 & 0.904 \\
\hline Age group: $<21$ & - & - & - & - \\
\hline Age group: $21-30$ & 0.892 & 1.039 & 0.596 & 1.811 \\
\hline Age group: 31 - 40 & 0.312 & 1.335 & 0.763 & 2.335 \\
\hline Age group: 41 - 50 & 0.438 & 1.254 & 0.708 & 2.219 \\
\hline Age group: > 50 & 0.901 & 0.961 & 0.512 & 1.804 \\
\hline Occupation: Did not work & - & - & - & - \\
\hline $\begin{array}{l}\text { Occupation: Professional/technical, managerial and } \\
\text { administration }\end{array}$ & 0.203 & 1.478 & 0.810 & 2.697 \\
\hline Occupation: Clerical & * 0.016 & 2.216 & 1.158 & 4.239 \\
\hline Occupation: Sales & $\begin{array}{l}\star \star \\
0.002\end{array}$ & 2.564 & 1.418 & 4.635 \\
\hline Occupation: Services & * 0.021 & 1.963 & 1.106 & 3.485 \\
\hline Occupation: Agricultural - self-employed & 0.126 & 1.555 & .884 & 2.735 \\
\hline Occupation: Industrial worker & ${ }^{*} 0.016$ & 2.011 & 1.139 & 3.551 \\
\hline Occupation: Other & 0.135 & 1.905 & 0.818 & 4.436 \\
\hline Parity: Primiparous & - & - & - & - \\
\hline Parity: Multiparous & 0.000 & 0.589 & 0.512 & 0.677 \\
\hline Parity: Grand multiparous & 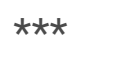 & 0.269 & 0.216 & 0.333 \\
\hline
\end{tabular}


Note: $* \mathrm{p}<0.05 ; * * \mathrm{p}<0.01 ; * * * \mathrm{p}<0.001$.

Table 3 displays the results of the binary logistic regression of the husband's involvement in ANC visits among the poor in Indonesia. Based on the education level, it can be seen that husbands who have a primary education level are 1.470 times more likely than no education husbands for husband's involvement in ANC visits (OR 1.470; 95\% Cl 1.050-2.058). Husbands who have secondary level education have a probability of 2.129 times compared to no education husband for husband's involvement in ANC visits (OR 2.129; 95\% Cl 1.520-2.982). Meanwhile, husbands who have a higher education level category are 3.618 times more likely than no education husbands for husband's involvement in ANC visits (OR $3.618 ; 95 \% \mathrm{Cl} 2.352-5.566)$. This information shows that the better the education of a husband, the greater the likelihood of the husband's involvement in ANC visits among the poor in Indonesia.

Apart from the education level, 3 other variables proved to be significant to influence the husband's involvement in ANC visits among the poor in Indonesia. First, type of place of residence. Husbands living in rural areas were 0.796 times more likely than husbands living in urban areas for the husband's involvement in ANC visits (OR 0.796; 95\% Cl 0.701-0.904). The results of this analysis indicate that husbands who live in urban areas have a higher probability of husband's involvement in ANC visits among the poor in Indonesia.

Second, the occupation of the husband. Husbands with occupation in the clerical category were 2.216 times more likely than husband did not work for husband's involvement in ANC visits (OR $2.216 ; 95 \% \mathrm{Cl}$ 1.158-4.239). Husbands with occupation in the sales category were 2.564 times more likely than husband did not work for husband's involvement in ANC visits (OR 2.564; 95\% $\mathrm{Cl} 1.418-4.635$ ). The husband with occupation service category had 1.963 times probability than husband did not work for husband's involvement in ANC visit (OR 1.963; 95\% Cl 1.106-3.485). On the other hand, husbands with occupation in the industrial worker category had a probability of 2.011 times compared to husband did not work for husband's involvement in ANC visit (OR 2.011; 95\% Cl 1.139-3.551).

Third, the parity of wife. Husbands with multiparous wives were 0.589 times more likely than husbands with primiparous wives for husband's involvement in ANC visit (OR 0.589; 95\% $\mathrm{Cl} 0.512-0.677$ ). Meanwhile, husbands with grand multiparous wives were 0.269 times more likely than husbands with primiparous wives for husband's involvement in ANC visit (OR 0.269; 95\% Cl 0.216-0.333). These findings inform that the more children a couple has, the less likely it is for the husband's involvement in ANC visits among the people in Indonesia.

\section{Discussion}


The results of the analysis found that the better the education of a husband, the greater the possibility of the husband's involvement in ANC visits among the poor in Indonesia. These findings inform that awareness and responsibility as a husband is in line with the level of education one has. The better the level of education, the better it is to understand the risk of pregnancy hazards that are currently undergoing the wife. Understanding more and more that pregnancy is not only women's business ${ }^{28,29}$. A study in Tanzania found that the involvement of the husband in ANC visits is a lifestyle that is considered modern ${ }^{30}$. Husband involvement was also found to encourage wives to use maternal services with better and more skilled midwives ${ }^{31,32}$.

Higher education level is known to be the main positive determinant of program performance in the health sector as indicated in several previous studies ${ }^{33-35}$. Otherwise, lower levels of education were found to be a barrier to program performance in the health sector 36,37 .

Husbands living in urban areas have a better chance of husband's involvement in ANC visits among the poor in Indonesia. This condition is possible because couples who live in urban areas have the opportunity to be exposed to better health information than couples who live in rural areas ${ }^{34,38}$. Additionally, several studies have informed that living in urban areas provides opportunities for better access to various health care facilities ${ }^{39,40}$.

The results of the analysis inform that occupation of the husband is one of the determinants of the husband's involvement in ANC visits among the poor in Indonesia. Specifically, a study in Pakistan states that the husband's involvement in ANC visits is influenced by income level. Lower-income has a lower probability of a husband's involvement in the ANC visit ${ }^{28}$. For poor families, the time that the husband has is more prioritized for seeking additional income than having to take the wife for ANC visits. Another study conducted in Myanmar found that the involvement of the husband is higher in financial support, but the involvement of the husband is lower in terms of maternity care and preparation for delivery ${ }^{32}$.

Finally, the results of the analysis show that the more children a couple has, the less likely it is for the husband's involvement in ANC visits among the poor in Indonesia. The previous study also informed the similar findings that parity is a determinant of the husband's involvement in the ANC visit ${ }^{32}$. Meanwhile, a study in Tanzania informs different findings. Husbands with grand multiparous wives were 1.658 times more likely than husbands with primiparous wives for husband's involvement in ANC visit ${ }^{41}$.

The limitation of this study is that it does not include cultural factors as one of the predictors that might influence the husband's involvement in ANC visits among the poor in Indonesia. Several previous studies have suggested that cultural factors are often found as a barrier to the husband's involvement in maternal health services ${ }^{42,43}$. On the other hand, in the context in Indonesia, it is often assumed that pregnancy and childbirth are the affairs of women, not men ${ }^{11}$.

\section{Conclusions}


Based on the results of the study, it could be concluded that there was an education level of the husband which was a determinant of the husband's involvement in ANC visits among the poor in Indonesia. The better the husband's education level, the greater the chance for the husband's involvement in the ANC visit. Apart from education level, 3 other variables were also found as determinants of the husband's involvement in ANC visits among the poor in Indonesia. The three variables were the type of place of residence, occupation of husband, and parity of wife.

\section{Declarations}

\section{Ethics approval and consent to participate}

The 2017 IDHS has passed ethical clearance from the National Ethics Committee. The respondents' identities have all been deleted from the dataset. Respondents have provided written approval for their involvement in the study. The author has obtained permission for the use of data for this study through the website: https://dhsprogram.com/data/new-user-registration.cfm.

\section{Consent for publication}

Not applicable

\section{Competing interests}

The authors declare that they have no competing interests

\section{Funding}

Not applicable

\section{Availability of data and materials}

Data cannot be shared publicly because of the data are owned by a third party and authors do not have permission to share the data. The 2017 IDHS data set name requested from the ICF ('data set of childbearing age women') are available from the ICF contact via https://dhsprogram.com/data/newuserregistration.cfm) for researchers who meet the criteria for access to confidential data.

\section{Authors' contributions}

ADL developed the proposal, analyzed and interpreted the patient data. RDW was a major contributor in conducting study, interpreting the data and writing the manuscript. RM was a major contributor in conducting study, interpreting the data and writing the manuscript. All authors read and approved the final manuscript.

\section{Acknowledgements}


The author would like to thank the ICF International, who has agreed to allow the 2017 IDHS data to be analyzed in this article.

\section{References}

1. Herbert Wau NR. Utilization of Antenatal Care (ANC) Services by Pregnant Women in Binjai City and Factors Affecting. J Kesehat Masy. 2020;33(5):390-8.

2. Ministry of Health Republic of Indonesia. Indonesia Health Profile 2018. 2019. 207 p.

3. Azhar K, Dharmayanti I, Tjandrarini DH, Hidayangsih PS. The influence of pregnancy classes on the use of maternal health services in Indonesia. BMC Public Health. 2020;20(1):1-9.

4. The World Bank Group, IBRD IDA. Mortality rate, neonatal (per 1,000 live births) | Data. 2016 The World Bank Group, All Rights Reserved. 2016.

5. Ahmed S, Fullerton J. Challenges of reducing maternal and neonatal mortality in Indonesia: Ways forward. Int J Gynecol Obstet. 2019;144:1-3.

6. Ismainar H, Subagio HW, Widjanarko B, Hadi C. To what extent do ecological factors of behavior contribute to the compliance of the antenatal care program in Dumai city, Indonesia? Risk Manag Healthc Policy. 2020;13:1007-14.

7. Jiwani SS, Amouzou A, Carvajal-Aguirre L, Chou D, Keita Y, Moran AC, et al. Timing and number of antenatal care contacts in low-and middle-income countries: Analysis in the Countdown to 2030 priority countries. J Glob Health. 2020;10(1).

8. Laksono AD, Rukmini R, Wulandari RD. Regional disparities in antenatal care utilization in Indonesia. PLoS One. 2020;15(2):e0224006.

9. Tarar MA, Khan YN, Ullah MZ, Salik MH, Akhtar S, Sultan T. Knowledge and attitude; pregnancy and antenatal care among young agrarian \& non-agrarian females in Faisalabad District, Pakistan. Pakistan J Agric Sci. 2019;56(1):261-73.

10. Sebayang SK, Efendi F, Astutik E. Women's empowerment and the use of antenatal care services: analysis of demographic health surveys in five Southeast Asian countries. Women Heal. 2019;59(10):1155-71.

11. Pratiwi NL, Fitrianti Y, Nuraini S, Rachmawati T, Laksono AD, Afreni M, et al. Concealed Pregnant Women or Kemel of Gayo Ethnic in Blang Pegayon District, Gayo Lues District, Aceh. Bull Heal Syst Res. 2019;22(2):81-90.

12. Rakhmadi MF. Women 's decision -making autonomy in the household and the use of maternal health services: an Indonesian case study Corresponding author: Midwifery. 2020;102816.

13. Pratita I, Laksono AD. "If this child eats, whatever she/he is asked ...": Exploration of Value of Children and Parenting Patterns in Javanese in the Besowo village, Kediri, East Java. Amerta Nutr. 2020;in press.

14. Mullany BC, Becker S, Hindin MJ. The impact of including husbands in antenatal health education services on maternal health practices in urban Nepal: Results from a randomized controlled trial. 
Health Educ Res. 2007;22(2):166-76.

15. Agushybana F. Influence of husband support on complication during pregnancy and childbirth in Indonesia. J Heal Res. 2016;30(4):249-55.

16. Teklesilasie W, Deressa W. Barriers to husbands' involvement in maternal health care in Sidama zone, Southern Ethiopia: A qualitative study. BMC Pregnancy Childbirth. 2020;20(1):1-8.

17. Titaley CR, Dibley MJ, Roberts CL. Factors associated with underutilization of antenatal care services in Indonesia: Results of Indonesia Demographic and Health Survey 2002/2003 and 2007. BMC Public Health. 2010;10.

18. Titaley CR, Hunter CL, Heywood P, Dibley MJ. Why don't some women attend antenatal and postnatal care services?: A qualitative study of community members' perspectives in Garut, Sukabumi and Ciamis districts of West Java Province, Indonesia. BMC Pregnancy Childbirth. 2010;10:1-12.

19. Yusuf M, Kodhiambo M, Muendo F, Kariuki J. Determinants of Access to Skilled Birth Attendants by Women in Galkacyo District, Somalia. Asian J Med Heal. 2017;4(4):1-9.

20. Kurniati A, Chen C-M, Efendi F, Elizabeth Ku L-J, Berliana SM. Suami SIAGA: Male engagement in maternal health in Indonesia. Health Policy Plan. 2017;32(8):1203-11.

21. Shefner-Rogers CL, Sood S. Involving husbands in safe motherhood: Effects of the Suami SIAGA Campaign In Indonesia. J Health Commun. 2004;9(3):233-58.

22. Bala R, Singh A, Singh V, Verma P, Budhwar S, Shukla OP, et al. Impact of socio-demographic variables on antenatal services in eastern Uttar Pradesh, India. Health Care Women Int. 2020;0(0):118.

23. Caulfield T, Onyo P, Byrne A, Nduba J, Nyagero J, Morgan A, et al. Factors influencing place of delivery for pastoralist women in Kenya: A qualitative study. BMC Womens Health. 2016;16(1):1-11.

24. Laksono AD, Wulandari RD, Efendi F. Determinants of hospital utilisation among urban poor societies in Indonesia. Int J Innov Creat Chang. 2020;12(9):375-87.

25. Sukirman R, Wahyono TYM, Shivalli S. Determinants of healthcare facility utilization for childbirth in Kuantan Singingi regency, Riau province, Indonesia 2017. BMC Public Health. 2020;20(1):1-10.

26. Islam MA, Kabir MR, Talukder A. Triggering factors associated with the utilization of antenatal care visits in Bangladesh: An application of negative binomial regression model. Clin Epidemiol Glob Heal. 2020;(April):0-1.

27. National Population and Family Planning Board, Statistics Indonesia, Ministry of Health, The DHS Program. Indonesia Demographic and Health Survey 2017 [Internet]. Jakarta; 2018. Available from: https://www.dhsprogram.com/pubs/pdf/FR342/FR342.pdf

28. Maken ZH, Nasir Idrees I, Zahid A, Zulfiqar A, Munib A, Hassan F, et al. Factors influencing father's antenatal and perinatal involvement in maternal health care. J Matern Neonatal Med. 2018;31(19):2569-75.

29. Sharma V, Leight J, Giroux N, Abdulaziz F, Nyqvist MB. "That's a woman's problem": A qualitative analysis to understand male involvement in maternal and newborn health in Jigawa state, northern 
Nigeria. Reprod Health. 2019;16(1):Article number 143.

30. Kashaija DK, Mselle LT, Mkoka DA. Husbands' experience and perception of supporting their wives during childbirth in Tanzania. BMC Pregnancy Childbirth. 2020;20(1):Article number 85.

31. Rahman AE, Perkins J, Islam S, Siddique AB, Moinuddin M, Anwar MR, et al. Knowledge and involvement of husbands in maternal and newborn health in rural Bangladesh. BMC Pregnancy Childbirth. 2018;18(1):Article number 247.

32. Wai KM, Shibanuma A, Oo NN, Fillman TJ, Saw YM, Jimba M. Are husbands involving in their spouses' utilization of maternal care services?: A cross-sectional study in Yangon, Myanmar. PLoS One. 2015;10(12):Article number e0144135.

33. Wulandari RD, Laksono AD. Education as predictor of the knowledge of pregnancy danger signs in Rural Indonesia. Int J Innov Creat Chang. 2020;13(1):1037-51.

34. Wulandari RD, Laksono AD. Determinants of knowledge of pregnancy danger signs in Indonesia. PLoS One. 2020;15(5):Article number e0232550.

35. Ipa M, Widawati M, Laksono AD, Kusrini I, Dhewantara PW. Variation of preventive practices and its association with malaria infection in eastern Indonesia: Findings from community-based survey. PLoS One. 2020;15(5):e0232909.

36. Rohmah N, Yusuf A, Hargono R, Laksono AD, Masruroh, Ibrahim I, et al. Determinants of teenage pregnancy in Indonesia. Indian J Forensic Med Toxicol. 2020;14(3):2080-5.

37. Laksono AD, Wulandari RD. The Barrier to Maternity Care in Rural Indonesia. J Public Heal From Theory to Pract. 2020;Online First.

38. Oguntunde O, Nyenwa J, Yusuf FM, Dauda DS, Salihu A, Sinai I. Factors associated with knowledge of obstetric danger signs and perceptions of the need for obstetric care among married men in northern Nigeria: A cross-sectional survey. BMC Pregnancy Childbirth. 2019;19(1):Article number 123.

39. Laksono AD, Wulandari RD, Soedirham O. Urban and Rural Disparities in Hospital Utilization among Indonesian Adults. Iran J Public Health [Internet]. 2019;48(2):247-55. Available from: http://ijph.tums.ac.ir/index.php/ijph/article/view/16143

40. Wulandari RD, Laksono AD. Urban-Rural Disparity: The Utilization of Primary Health Care Center Among Elderly in East Java, Indonesia. J Adm Kesehat Indones [Internet]. 2019;7(2):147-54. Available from: https://e-journal.unair.ac.id/JAKI/article/view/11267

41. Gibore NS, Ezekiel MJ, Meremo A, Munyogwa MJ, Kibusi SM. Determinants of men's involvement in maternity care in dodoma region, central Tanzania. J Pregnancy. 2019;2019:Article number 7637124.

42. Davis J, Vaughan C, Nankinga J, Davidson L, Kigodi H, Alalo E, et al. Expectant fathers' participation in antenatal care services in Papua New Guinea: A qualitative inquiry. BMC Pregnancy Childbirth. 2018;18(1):Article number 138.

43. Davis J, Vyankandondera J, Luchters S, Simon D, Holmes W. Male involvement in reproductive, maternal and child health: A qualitative study of policymaker and practitioner perspectives in the Pacific. Reprod Health. 2016;13(1):Article number 81. 